\title{
O romance brasileiro contemporâneo sob o olhar de $O$ Ponto Cego
}

Cimara Valim de Melo ${ }^{1}$

O olhar é o fundo do copo do ser humano.

Walter Benjamin

\section{Introdução}

Com uma vasta obra ficcional desenvolvida ao final do século $X X$, em tempos de democratização e redefinição identitária do Brasil contemporâneo, a escritora gaúcha Lya $\mathrm{Luft}^{2}$ deixou um importante legado à romanesca contemporânea no que tange à relação entre intimismo e sociedade. A prospecção do universo interior humano e de suas dissonâncias em relação ao mundo externo é, por sua vez, um relevante caminho para a análise de sua obra, que se embebe da narrativa de introspecção produzida ao longo dos séculos XIX e XX na América Latina e na Europa desde Dostoiévski.

Novas perspectivas surgem na romanesca luftiana do final dos anos de 1990, com a publicação de O ponto cego (1999). Seja pela busca de novas possibilidades estéticas em

\footnotetext{
${ }^{1}$ Cimara Valim de Melo é doutora em Estudos de Literatura pela Universidade Federal do Rio Grande do Sul (UFRGS), pesquisadora visitante de pós-doutorado no King's Brazil Institute do King's College London e professora do Instituto Federal de Educação, Ciência e Tecnologia do Rio Grande do Sul (IFRS). Suas pesquisas envolvem as relações tempo-espaço no romance do Brasil contemporâneo, bem como o processo de internacionalização da literatura brasileira no século XXI. É de sua autoria o livro O lugar do romance na literatura brasileira contemporânea (2013). Este artigo tem como base parte de seus estudos de mestrado sobre o romance luftiano, os qual culminaram com dissertação Lya Luft: percursos entre intimismo e modernidade.

${ }^{2}$ Romances de Lya Luft: As parceiras, 1980; A asa esquerda do anjo, 1981; Reunião de família, 1982; O quarto fechado, 1984; Exílio, 1987; A sentinela 1994; O ponto cego, 1999; O tigre na sombra, 2012.
} 
sua criação literária, seja pela necessidade de problematização dos desvãos sociais dessa época, Lya Luft redimensiona o modo de suas personagens verem e interagirem com o mundo atual, impingindo nuances metalinguísticos ao longo da narrativa. $\mathrm{O}$ olhar infantil é, para isso, utilizado, mesclado a reflexões acerca da condição humana, a fim de estabelecer um contato intertextual com seus romances anteriores. Contudo, as diferenças existentes entre eles e $O$ ponto cego são notáveis, a começar pela perspectiva singular do narrador frente ao narrado, passando pelo modo como ocorre a difusão do enredo, do tempo e do espaço e culminando na oscilação da linguagem.

Além disso, oculta na solitária individualidade do "Renegado" narrador, podemos perceber a preocupação da autora com elementos paradoxais: as voláteis relações humanas; a mecanização social; o abismo existente entre a morte e seu suplemento: a vida; as máscaras usadas por indivíduos carentes de identidade; o centramento na interioridade das personagens, em face às precariedades a que os homens são submetidos; a não aceitação das diferenças; as perversidades provenientes de ações cotidianas. É esse "ponto cego" criado por Lya que o presente estudo busca conhecer: "a possibilidade além da superfície, o concreto afirmado na miragem" (Luft, 2003, p.9).

\section{O labirinto romanesco de $O$ ponto cego}

No romance $O$ ponto cego, erguem-se as paredes de um labirinto metafórico, no qual as personagens se deparam com um riquíssimo universo simbólico que deixa escapar muitos dos paradoxos existentes na própria natureza humana. Retratos, espelhos, portas, janelas, bichos-da-seda, pequenos pássaros e cavalos alados são fragmentos de teias e teares que tecem e descosem a vida. Em O ponto cego, é a personagem masculina que governa o tear e mescla, no ato de criação, as mais 
inusitadas vidas, os mais intrincados relacionamentos. $\mathrm{O}$ ato da tecelagem retoma o romance $A$ sentinela, de Lya Luft, no qual há também o movimento de tramar os fios da vida e de descoser o passado através das memórias de Nora. Como que manejando um tear, o Menino não só cria como também narra o que vê ao seu redor.

Qual é a história que eu aqui quero contar? De gente que é muito esquisita, de criança que é muito solitária, de um Menino que sabe muita coisa, e de que saber é muito perigoso.

O estranho é que sei sem ter conhecido, penso que ainda nem foi posto em palavras; mais estranho ainda, o que invento pode mais tarde acontecer. Quem verdadeiramente dita as falas, quem comanda nesse palco?

Eu sou o narrador e personagem, eu escrevo o roteiro, sou eu quem salta entre os cenários e observa dos bastidores.

Mas às minhas costas sopra essa voz mais forte do que eu: o anjo que fia e tece e borda, e me prende nesse enredo. Não calculei bem os seus poderes, nisso me perdi. (Luft, 2003, p.77).

O Menino, narrador e protagonista do romance, não detém com exclusividade a responsabilidade sobre o seu destino, a sua história. Desse modo, não consegue desfazer nem resolver os problemas que trazem dor ao seu íntimo. O culpado e a vítima, o violento e o inocente, o maldito e o abençoado, o criminoso e a testemunha, o hipócrita e o justiceiro, o abandonado e o reencontrado, todas essas vozes são encontradas nas personagens, a começar por ele, Anão, criança e adulto. “As ilusões não continham mais o tempo, e o costurado voltava a descoser" (Luft, 2003, p.46), diz o narrador, utilizando- 
se da memória para refletir sobre a frágil teia familiar, prestes a desintegrar-se por completo.

Cada capítulo representa, por meio das relações entre narrador e narrado, a degradação do ser, fazendo-nos refletir sobre as divagações de um estrangeiro em seu próprio ninho, sem encontrar saída para a situação em que se encontra, mesmo que sua mão esteja também guiando o tear.

No primeiro capítulo, "História de Mãe e de Menino", percebemos que estamos no final da narrativa, ou melhor, no início de outra etapa que se forma na existência do narrador, atormentado pelas trágicas reviravoltas do cotidiano. Lúcido da realidade que tem pela frente, o que resta é reconstruir em sua memória, com as migalhas que ficaram pelo caminho, a própria identidade. Assim, ele começa a repensar sobre o vínculo com a mãe. Ao reavaliar o passado problemático, enxerga em seu processo de criação erros transformados em consequências que geram a solidão pela falta da mãe. A perda pela falta de contato com a mãe é irreparável, metaforizada pelo desajuste das funções de seu próprio corpo, que pára de crescer, mas não deixa de ficar a cada dia diferente. Essas estranhas mutações corpóreas incluem a pele a ocultar um interior que cresce e dói, com o perigo de rachar, fender, explodir terrivelmente em todas as direções.

O que vai ser de mim? Eu me pergunto isso todos os dias, uma porção de vezes. O que vai espirrar nas paredes, o que vai-se derramar no chão: a merda ou o sonho?

O tempo que rói e corrói precisa ser reinstaurado, quem conta histórias pode sobrepor muitas camadas de imaginário e real pois sabe que os limites são tênues, e poderosa a liberdade com todos os seus perigos. 
(É isso que eu faço. Eu manejo as minhas criaturas, invento e desinvento, e faço acontecer.) (Luft, 2003, p.16)

Sozinho em sua incompletude, o protagonista inicia uma narrativa desencontrada de reconstrução da própria história a partir daquela vivida por seus familiares. Não são apenas memórias, já que elas formam uma íntima colcha de retalhos, juntamente com devaneios, digressões e questionamentos.

A Mãe, sufocada pela camuflada insegurança do Pai, vive momentos de repressão e tristeza, percebidas por aquele que a ama de modo tão peculiar: "Eu me pergunto se até o fim de sua vida ela vai querer isso que tem. Nunca mais a palavra alegria." (Luft, 2003, p.42) Mas ele já tem a chave da resposta em sua mão: "Meu Pai a iria perdê-la por prendê-la tanto" (Luft, 2003, p.23). Apesar de a mulher conviver com a aflição interior, há também bons sentimentos que sobrevivem no âmago de seu ser. Entre eles estão o carinho que nutre pelo filho; a compaixão solidária que sente por sua mãe, vítima da insanidade mental; o ardor incontrolável pelo Outro que chega à casa, transformando a vida de todos sem um aviso prévio, sem uma decisão criadora do Menino:

Minha Mãe e o Moço concentravam-se no ardor deles que tudo contagiava, espalhando-se em uma estranha agitação na casa, no campo, nas pessoas que se viam diferentes. [...]

E eu, Menino doente, fora perdido de minha Mãe. E aquilo me doeu como se me furassem as tripas com uma faca de castrar, sete facas varando o meu peito ineficiente.

[...] para ele, mais sedutores que o vento, o mar e o cavalo, eram os olhos de minha Mãe. (Luft, 2003, p.126). 
Não podemos nos esquecer de que recebemos os fatos filtrados pela perspectiva do Menino, a qual é dotada de fantasia e intenções obscuras. Ao mesmo tempo em que sua recordação rememora a relação carinhosa com a mãe, sombras pairam na família quando seu olhar volta-se ao Pai. Ele constitui uma barreira que impede o diálogo e o bom convívio entre todos, mas não é o único culpado, pois sua mãe torna-se cúmplice da situação que se instala na família. Não escapa aos olhos do narrador a insegurança daquele quanto à estabilidade de seu campo de domínio; a dificuldade de cultivar o afeto entre todos os membros da família; o desgosto por ter um filho "esquisito", que fugiu de seu controle por "ser diferente"; a mágoa pela morte da primeira filha, Letícia; a falsidade moral que o leva a trair a esposa e a tomar posse dos bens da mesma. Tudo é observado minuciosamente pelo Menino, de um ângulo que somente este consegue captar. Por esse "ponto cego", as fraquezas do Pai são postas à mostra, tornando-se uma fácil presa àquele que se alimenta de sua solidão.

Eu sempre observo meu Pai aqui da minha perspectiva. Quando ele não percebe eu o encaro, erguendo um pouco a cabeça.

Agora há uma novidade. Ele finalmente se decidiu: trocou a venda por um olho de vidro, azul como o outro, igualzinho. Mas eu sei que com esse olho ele não pode me ver. (Luft, 2003, p.80)

Além de observar que o Pai não "enxerga" tão bem quanto ele as obscuridades da vida, avaliando tudo o que quer pelo único olho, pelo único ângulo, o do alto, o Menino percebe que a cegueira paterna deve-se principalmente a sua resistência em mudar o modo de ver o mundo. Também seus pés pequenos, singularmente delicados, dão a sensação de uma base fraca. Com isso, mais que um controlador, o Pai torna-se, com a 
ausência da Mãe, um estrangeiro na família, um exilado que, em seu desespero, curva-se às decisões da segunda filha, assim como curvara-se à morte da primeira, desfigurando a identidade que procurava manter inteira. "Meu Pai [...] vivia numa perspectiva de onde não se enxerga o essencial. [...] por arrogância, por cegueira ou por destino, meu Pai foi o mais que todos exilados." (Luft, 2003, p.125).

Já de início, o narrador situa o seu lugar na narrativa, ou melhor, seu não lugar engendrado no suplemento, frente a um vazio social percebido nos espaços de sua própria casa. Segundo Ecléa Bosi (1994, p.436), o espaço que a criança vivencia “como o dos primitivos, é mítico, heterogêneo, habitado por influências mágicas." Tudo é penetrado de "afetos, móveis, cantos, portas e desvãos". Porém, em O ponto cego, não temos somente uma criança que narra, temos um ser poliédrico, complexo. Nesse espaço que subverte o sagrado, o que lhe restam são os cantos, as sombras e os restos, as escadas e os corredores, o embaixo-escuro:

Não quero perder as minhas asas, por isso não vou crescer - apenas me desenrolar. Assim me infiltro em todas as fendas. Assim caibo em toda parte e ninguém desconfia de mim.[...]

Esse é o meu divertimento. Eu gosto do embaixo, do debaixo, do escuro. Meu lugar é onde se represa o tempo e a minha vontade se exerce. (Luft, 2003, p.32).

No segundo capítulo, "História de Pai e Mãe", amplia-se a problematização do relacionamento conjugal. Como observador, em um "ponto cego" para os familiares, ele vê o que as aparências encobrem na vida dos pais. Há uma Mãe dominada pelo marido, infeliz e acomodada, sem perspectivas de mudança. Há um Pai ausente, inseguro, infiel, que tenta padronizar a família pelos seus moldes. Há também uma avó, a mãe de sua 
Mãe, marcada pela insanidade. Uma pessoa que se prendia em padrões de beleza para tentar inutilmente fugir da força do tempo; contudo, liberta-se dessa realidade, pousando em um labirinto de fantasias que preenchem o vazio formado pela não aceitação da velhice:

Várias vezes repetiu:

Os grilos, como estão cantando hoje!

E dirigia-se a umas pessoas que não estavam ali. Ou, estavam e só ela via? Não tive receio: eu conheço bem essa vida que se remexe e murmura no invisível.

Talvez o universo de Vovó agora seja um esconderijo de ar, um mundo aéreo onde ela, menina feliz, não precisa dizer nem sim, nem não. Deixou de sofrer.

Seu círculo estava fechado, ela vencera o tempo: a loucura fizera mais bem do que todas as dietas, cirurgias e plásticas. (Luft, 2003, p.51).

Há também uma irmã supervalorizada em detrimento do irmão, causando um desequilíbrio nos enlaces afetivos. Ela é a concentração de sentimentos represados no pai com a morte de Letícia, a primeira filha: “[...] só lhe restou essa, e todo amor e a culpa e o medo se concentraram nela, para seu bem, para seu mal" (Luft, 2003, p.60).

No terceiro capítulo, "História de Menino sozinho", destaca-se a retribuição de carinhos e, principalmente, de desamores entre as pessoas. O cordão umbilical afetivo do Menino é ainda muito preso à figura materna, que atua como sua protetora. O "crescimento" exterior cede espaço ao interior, fazendo com que seu corpo desobedeça aos conceitos de "normalidade" e entre em colapso estrutural. O Menino faz descobertas quando toma conhecimento do passado, do presente e do futuro. Em relação ao 
passado, analisa a história do tio, repleta de mortes e renascimentos. “O meu tio nada nas águas de duas mortes: dessa viagem não se volta inteiro." (Luft, 2003, p.99). Quanto ao seu presente, ele remói a solidão da Mãe, que também lhe traz sofrimento, e observa a base fraca na qual o pai vive, sem um alicerce moral e afetivo, tornando-o ainda mais vulnerável. “No resto ele é meio tosco sobre esse pedestal precário: é como se não tivessem acabado de fazer a escultura." (Luft, 2003, p.89). Já em relação ao futuro, questiona o que será dele em um amanhã de perigosas possibilidades. Não encontrando respostas, decide estagnar-se no hoje. Suas reflexões sobre si e o mundo são também indagações sobre a criação literária, o mundo imaginário e o real, brincando inconsequentemente com seus poderes de narrador-criador da história.

No quarto capítulo, "História do vento do mar", é desenvolvida a metáfora das lembranças que vão e vêm, daquilo que não se compreende, mas se sente. $\mathrm{O}$ vento de um mar distante, um mar de memórias, está presente nos pensamentos do Menino, juntamente ao cavalo alado, que livremente voa, como a mente do Menino. O narrador recorda as desventuras de seu tio, o único, além de Letícia, menina morta, que recebe nome. Sua identidade revelada destaca-se em meio aos seres sem nome que ali (sobre)vivem. Fernando tem seu nome descortinado por preservar sua própria face interior, sem se preocupar em revelar ao Menino o que sente e guarda na memória. Suas dores tocam o cerne do Menino, que dele se aproxima e com ele compartilha momentos de sinceridade. É ele quem fala ao menino sobre o "vento do mar", tragador de lembranças que existem além do tempo.

No último capítulo, "História de Mãe e Moço", o Menino - que se transforma paulatinamente em Anão - tem suas energias físicas cada vez mais debilitadas, como se uma vida interna absorvesse a externa. O cavalo alado de sua imaginação fica sem as rédeas, pois o narrador perde o controle sobre sua criação. Assim, o Intruso instala-se em sua casa como namorado da irmã e, com isso, a Mãe esquece-se do Menino. O Moço 
e, logo depois, a Mãe acabam por desaparecer de sua vida, sem que ele nada possa fazer enquanto criador da história: "As engrenagens que pus em movimento assumiram o seu ritmo fora do meu controle e compreensão." (Luft, 2003, p.140).

Também o pai fica sem controle da vida familiar. Não coordena mais a filha preferida e perde sua esposa. Em meio à cegueira de cada indivíduo, resta um Menino cuidado por suas Tias, alheias aos problemas existentes. Um Menino que se desfaz como o homem de $A$ moça tecelã (1991, p.56-57), mas pelas próprias mãos. Um Menino que narra muitas vidas em uma história, mas não consegue mudar a sua.

\section{Tempo e narrativa em $O$ ponto cego}

O que é o tempo em $O$ ponto cego, senão um aglomerado de fagulhas desordenadas em um espaço vazio? O tempo é, talvez, o elemento mais mutável da narrativa, remexendo presente, passado e futuro. Mesmo havendo memórias acerca do passado, nem sempre elas são descritas como se fossem realmente lembranças, misturando-se ao tempo presente. Face a tal construção, já no início do romance, o narrador faz questão de alertar o quanto sua perspectiva é pouco confiável:

Algumas das coisas que vou contar aqui eu vi e vivi; de muitas suspeitei, apanhei soltas no ar, meu coração as escutava soprando nas frestas. Outras, ainda, as pessoas revelaram sem saber. [...]

$\mathrm{Eu}$ simplesmente fui reunindo mentiras e testemunhos: pois o que passou e o que está por vir e o que jamais aconteceu, paira no ar como a voz do mar continua depois que o fundo de areia se transformou num perfumado capim, riachos e cavalos, e pessoas com seus destinos desde sempre escritos. (Luft, 2003, p.17-18). 
A voz do tempo relaciona-se a um conjunto de lembranças, cuja cisão subverte qualquer delimitação cronológica e racional, fragmentando a narrativa com seu fluxo dinâmico. Para retomarmos a mobilidade temporal, dois exemplos merecem destaque. O primeiro refere-se ao aparecimento do Moço, narrado detalhadamente ao final da história, mas retomado em outros momentos anteriores da narrativa: “[...] um dia um visitante montou no cavalo do tempo e galopou - e ficou desaparecido" (Luft, 2003, p.31). Outro exemplo é quanto à atitude inesperada da mãe ao final do livro, a qual é mencionada ao longo da história, como se fizesse parte de um futuro próximo, já conhecido. “Quando minha Mãe me deixasse de fora, acuado por muitos tormentos eu subiria até meu quarto e tiraria de baixo da cama a caixa com meus bichos." (Luft, 2003, p.106).

Para Ecléa Bosi, a memória tem uma importante função no processo psicológico, liberando milhares de pormenores provenientes da experiência passada:

A memória permite a relação do corpo presente com o passado, e, ao mesmo tempo, interfere no processo "atual" das representações. Pela memória, o passado não só vem à tona das águas presentes, misturando-se com as percepções imediatas, como também empurra, "desloca" estas últimas, ocupando o espaço todo da consciência. A memória aparece com força subjetiva ao mesmo tempo profunda e ativa, latente e penetrante, oculta e invasora. (Bosi, 1992, p.46-47).

É nessa liberdade memorialística que o enredo se dispersa, desgovernando a lógica "início, meio e fim". Mesmo não conseguindo controlar o tempo, o narrador ele tem noção de suas forças. O tempo que luta contra o narrador é comparado a um bicho-da- 
seda esfomeado que devora tudo aos poucos, "uma lesma gorda e úmida grudada à alma" (Luft, 2003, p.49), é aquele que roça seu bafo na pele do Menino.

De acordo com a concepção de Norman Friedman, podemos relacionar o Menino ao narrador protagonista e ao narrador-testemunha ("I" as witness), já que, mesmo sendo o ponto-chave do enredo, sua posição é marginalizada, descentralizada. Lígia Chiappini explica a categoria de narrador-testemunha:

Ele narra em primeira pessoa, mas é um "eu" já interno à narrativa, que vive os acontecimentos aí descritos como personagem secundária que pode observar, desde dentro, os acontecimentos, e, portanto, dá-los ao leitor de modo mais direto, mais verossímil. Testemunha, não é à toa esse nome: apela-se para o testemunho de alguém, quando se está em busca da verdade ou querendo fazer algo parecer como tal.

No caso do "eu" como testemunha, o ângulo de visão é, necessariamente, mais limitado. Como personagem secundária, ele narra da periferia dos acontecimentos, não consegue saber o que se passa na cabeça dos outros (...). (Leite, 1997, p.37-38).

É claro que, mesmo estando deslocado no meio familiar, é ele quem protagoniza a história. Por isso, não participa da vida familiar e dos laços afetivos, mas se inclui no lugar que ele próprio criou para si. Podemos, assim, dizer que, no âmbito da narrativa, é ele o narrador-protagonista; contudo, no âmbito das relações sociais, não passa de uma mera testemunha da dissolução de sua família, à margem da história.

O narrador utiliza-se do monólogo interior. Esse recurso de expressão da interioridade traz à tona os pensamentos do Menino, suas recordações passadas, suas dúvidas e profecias sobre o futuro da família. Ao longo da narrativa, temos frases 
marcadas entre parênteses, as quais podem ser vistas como divagações ainda mais ocultas, segredos nas entrelinhas de suas invenções. Carregadas de significados, elas são chave para compreendermos o que se passa na atmosfera espiritual do narrador. Elas nos dão a certeza de que nele não vive apenas uma criança, mas um ser mais complexo, descoberto em seu próprio monólogo. Segundo Beth Brait (2004, p.62), “o monólogo interior é o recurso de caracterização de personagem que vai mais longe na tentativa de expressão da interioridade."

As palavras de Antonio Candido sobre a personagem da ficção romanesca relacionam-se ao tratamento dado por Lya Luft a suas criações, que extrapolam o domínio literário. Para ele, o romance moderno explorou as personagens "como seres complicados, que não se esgotam nos traços característicos, mas têm certos poços profundos, de onde pode jorrar a cada instante o desconhecido e o mistério" (Candido, 2002, p.60). Candido admite a formação de seres misteriosos e inesperados na literatura moderna, que carecem de coerência e sugerem o desvendamento das aparências no homem e na sociedade. A superação de um esquema fixo ampliou a complexidade dos seres. Abriram-se, com isso, possibilidades de conhecimento mais completo acerca das relações, resguardadas as diferenças entre o Homo fictus e o Homo sapiens.

[...] o romance, ao abordar as personagens de modo fragmentário, nada mais faz do que retomar, no plano da técnica de caracterização, a maneira fragmentária, insatisfatória, incompleta, com que elaboramos o conhecimento dos nossos semelhantes. Todavia, há uma diferença básica entre uma oposição e outra: na vida, a visão fragmentária é imanente à nossa própria experiência; é uma condição que não estabelecemos, mas a que nos submetemos. No romance, ela é criada, é estabelecida e racionalmente dirigida pelo escritor, que delimita e 
encerra, numa estrutura elaborada, a aventura sem fim que é, na vida, o conhecimento do outro. (Candido, 2002, p.58).

As possibilidades interpretativas que se abrem ao lermos e analisarmos um romance como O ponto cego, conduzem-nos ao que Umberto Eco chama de obra aberta. O mundo interior, vivificado na mente do Menino, conduz-nos ao movimento da obra, a sua abertura a "uma multiplicidade de intervenções pessoais", a uma estrutura incompleta, "a acabar". (Eco, 2003, p.62) Por meio de sua visão prismática, dispersiva, podemos entender o Menino como uma personificação da vida ou até mesmo da arte plurívoca um valor contemporâneo analisado por Eco:

Este valor que a arte contemporânea procura intencionalmente, aquele que se tentou identificar em Joyce, é o mesmo que procura realizar a música serial, libertando a audiência dos trilhos obrigatórios da tonalidade e multiplicando os parâmetros com que organizar e degustar o material sonoro; é o que busca a pintura informal quando tenta propor não mais uma, mas várias direções de leitura de um quadro; é ao que visa o romance quando não nos conta mais uma única história e um único enredo, mas procura endereçar-nos, num só livro, à individuação de mais histórias e enredos. (Eco, 2003, p.92).

Temos, então, nessa busca desenfreada de que nos fala Eco, a pulverização do enredo no romance, que, de acordo com Samira Mesquita (2003, p.45), ocorre "na medida em que se desestruturam as categorias de tempo e de espaço". O espaço da pluralidade ficcional embrica-se à descategorização do tempo, avesso à qualquer regra que molde a sua ilogicidade à ação da cronologia. A plurivocidade de $O$ ponto cego é ainda maior pela 
valorização do pormenor, que concede à narrativa um modo peculiar de representar a realidade. Erich Auerbach (2004, p.491), quando se refere ao romance moderno, diz que "muitas personagens, ou muitos fragmentos de acontecimentos, são articulados por vezes frouxamente de tal forma que o leitor não consegue segurar constantemente qualquer fio condutor determinado." Há assim a reconstrução “a partir de uma série de farrapos de acontecimentos, com personagens constantemente mutantes, por vezes reaparecidas". O detalhamento recortado pelas mãos criadoras do Menino privilegia seres, cenas e sentimentos familiares significativos em sua individualidade, os quais são reestruturados e realocados pelo ato de narrar.

Essa variedade de impressões e recomeços promove, no livro de Lya Luft, a visão dinâmica de tudo o que é remexido pela memória. Ao revirar o passado e centrar-se em pormenores cotidianos, o Menino prefere fatos e pessoas que possam desencadear momentos de autoanálise e descobertas íntimas. Inúmeras situações diárias, em momentos selecionados pela memória, ocasionam buscas reflexivas na personagem que narra. São expressas no romance partículas de uma suposta realidade. Segundo Anatol Rosenfeld, esse desmantelamento da ordem, dada a proximidade do "eu” na narrativa, são característicos do romance moderno:

A enfocação microscópica aplicada à vida psíquica teve efeitos semelhantes à visão de um inseto debaixo da lente do microscópio. Não o conhecemos mais como tal, pois, eliminada a distância, focalizamos apenas uma parcela dele, imensamente ampliada. Da mesma forma se desfaz a personagem nítida, de contornos firmes e claros, tão típica do romance convencional. Devido à focalização ampliada de certos mecanismos psíquicos perde-se a noção da personalidade total e do seu "caráter", que já não pode ser elaborado de modo plástico, ao longo de 
um enredo em seqüência causal, através de um tempo de cronologia coerente. Há, portanto, plena interdependência entre dissolução da cronologia, da motivação causal, do enredo e da personalidade. (Rosenfeld, 1996, p.85).

A desorganização dos elementos que regem a estrutura do romance tradicional desordena o feixe de lembranças e repercute na composição do indivíduo romanesco. "[O ser humano,] Eliminado ou deformado na pintura, também se fragmenta e decompõe no romance. Este, não podendo demiti-lo por inteiro, deixa de apresentar o retrato de indivíduos íntegros." (Rosenfeld, 1996, p.85) Máscaras não faltam no romance de Lya, como percebemos na fala do Menino: “Não posso mostrar fraqueza ou vou ser moído e esfarelado. Preciso disfarçar que me sinto tão cansado." (Luft, 2003, p.83). De acordo com Simone Sampaio Silva, o olhar sagaz do menino, não adestrado nem conformado com a realidade limitadora na qual está inserido, proporciona-lhe um conhecimento aprofundado dos perigos que permeiam as máscaras humanas:

Como manter-se seguro após ter observado as máscaras que cobrem cada face e a camada subterrânea de cada relação humana? Haveria saída para quem vê o mundo pelas frestas, pelas beiradas, negando-se a ser mais uma peça em um jogo de máscaras? O narrador-menino projeta o seu olhar para o espaço das relações familiares, expondo os fios que compõem essa teia e rejeitando sua própria posição nesse “jogo muito perigoso". Julgando-se seguro e forte em um espaço imaginário, de onde observa os personagens e histórias que compõem sua vida, o menino vai captando evidências do mundo e elaborando suas 
representações a partir de uma perspectiva bastante peculiar. (Silva, 2001).

O Menino observa as máscaras, ciente de que também tem as suas. Rejeita sua posição, mas se considera o próprio criador de sua história: "Assim eu inventei, assim eu decretei, assim é." (Luft, 2003, p.9) Julga-se seguro e forte, mas o próprio corpo é símbolo de suas fraquezas, já que não mais comporta sua imensidão interior, temendo explodir, rasgar-se. Com essa dificuldade de adaptar-se a si e ao mundo, torna-se grotesco, quase inumano, bestial. O grotesco, de acordo com as palavras de Rosenfeld, é a expressão do caos que faz do homem apenas ruínas. ${ }^{3} \mathrm{O}$ mundo caótico, por sua vez, tem suas origens na figura humana que se desumaniza, estabelecendo um jogo paradoxal. Muito presente na literatura luftiana, o ápice da literatura grotesca paira em Kafka, em seu modo de apresentar-nos o homem às voltas do absurdo. A ordem, na arte moderna,

[...] é apenas aparente, no funda reina o caos. Reais, verdadeiros são as ruínas e os esgares atrozes. Agitamo-nos num mundo de aparências, de máscaras, num mundo que é "representação". No fundo [...] somos bonecos estrebuchando, com trejeitos grotescos, nas cordas manipuladas pela vontade cega e inconsciente; palhaços a se equilibrarem, aos

\footnotetext{
${ }^{3}$ As ruínas estão associadas à ação do tempo no espaço (individual ou coletivo). Elas constituem partes de um todo que se perdeu, restos ou vestígios de uma realidade em vias de extinção. Representam o fragmento de um outro tempo, e, paradoxalmente, a abertura para perspectivas vindouras. Em sua conexão íntima com o passado, as ruínas também representam a memória, a ausência, o vazio. As marcas do tempo estão nelas presentes, pois elas são uma espécie de documento silencioso de algo que foi destruído, mas que se conecta com o presente e o futuro em sua espacialidade. Por seu aspecto fragmentado e incompleto, a ruína suscita uma série de leituras, recorrentes no universo literário. Nesse sentido, é importante recorrer a Benjamin (1986, p. 31), que compara ruínas a alegorias por seu aspecto fragmentário: "As alegorias são, no reino dos pensamentos, o que são as ruínas no reino das coisas". A perspectiva de ruínas como símbolo da fragmentação interior vivida pelas personagens rege a utilização do termo no presente artigo.
}

Brasiliana - Journal for Brazilian Studies. Vol. 3, n.1 (Jul. 2014). ISSN 2245-4373. 
tropeços, no circo do Ser absurdo. Na falência de todos os sentidos e valores, resta só um sentido: o salto mortal para o Nada.(Rosenfeld, 1996, p.66).

Há imagens e cenas grotescas em O ponto cego, assim como em outros romances, mas aqui elas são recriadas pelo próprio narrador. Em As parceiras, a anã-demente Sibila também brincava com seus vermes fabricadores de seda, figura de horror para Anelise; em $A$ asa esquerda do anjo, um verme sem identidade remexe-se nas entranhas de Gisela, sendo posteriormente expelido por ela em uma cena de lucidez e alucinação; em $O$ quarto fechado, o corpo imenso de Ella definha ao longo de anos em uma cama, excretando grunhidos, odores e excrementos; em Exílio, volta o Anão sarcástico, Gnomo, mas há também o Menino débil, uma criatura espantosa para a narradora, que dela se afasta, mas não de suas próprias criaturas; em $A$ sentinela, a cabeça decepada do pai de Nora ainda aparece, em sua memória, no jardim da casa.

Em O ponto cego, o corpo do narrador - Anão, Gnomo - parece ser o aspecto de maior incidência do grotesco. Ele se recusa a seguir seu curso normal, provocando estranhamento e repugnância. Está em transformação constante, como se um ser vivo em metamorfose quisesse sair de seu interior. É criança - narra entre sete e oito anos mas seus pensamentos vão além do universo infantil: "Sei que está chegando a hora, alguma hora: porque já não sou criança por dentro. Vou me abrir como uma fruta podre, a pele rachando." (Luft, 2003, p.117).

Sente dores em seu corpo, a pele racha, não cresce mais, mesmo com remédios e vitaminas. Sua visão ofusca-se depois que a mãe vai embora. Sente um repuxar que causa dor em seus ossos. Os cabelos ficam mais ralos e os cílios parecem estar caindo, tornando-o, em sua opinião, cada vez mais parecido com os vermes que vivem na caixa. 
Sofre "na carne o desconexo e o desencontrado" (Luft, 2003, p.77), fruto de suas próprias escolhas.

Mas a verdade é que em algum momento meu passo falhou; se tive dons eu os confundi, apertei botões errados, desestruturei o que pretendia construir.

Eu, que me julguei único dono dos segredos, senhor da pedra de onde o diabo se mira e ri sozinho, eu, que alforriei minha Mãe para que ela finalmente tivesse a sua vida - eu não fiz parte dessa sua escolha: isso eu não soube prever.

Perdi o controle sobre minhas histórias, como se agora elas me inventassem, mas competentes do que eu.

Também não pude prever o desequilíbrio do tempo no meu relógio, os ponteiros girando ao contrário ou mais depressa, para lá, para cá. Nem consegui calcular os preços que todos pagaríamos, porque a gente sempre tem de pagar por suas escolhas ou maquinações. (Luft, 2003, p.139).

Além do corpo, o grotesco manifesta-se em atitudes e estranhezas do Menino, que causam repulsa por saírem dos limites da "normalidade". Para Maria Osana de Medeiros Costa (1996, p.20), “as imagens grotescas têm, na obra de Lya Luft, uma função satírica e de contraste das mais singulares." Satírica porque deformam e denunciam aspectos da vida humana; de contraste porque trazem consigo o que choca por ser diferente, bizarro. Seu divertimento é, quando vai pescar, rasgar minhocas em duas partes, deixando escorrer o suco de suas vidas; criar seus bichos-da-seda, observando o modo como se remexem provocando nojo nos familiares; decapitar os 
pintinhos com as mãos para pavor de sua Mãe. Cenas, de algum modo, análogas às mutilações pelas quais passam os indivíduos no romance.

\section{Intersecções ente literatura e sociedade}

O romance, enquanto gênero literário intrincado à modernidade, é entrelaçado à sociedade da qual se origina, com as suas crenças e ilusões, buscando compreendê-la, indaga-la, subvertê-la. Tal relação, para João Alexandre Barbosa (1986, p.31), recai sobre as ideias de intemporalidade e ubiquidade. "As inadequações entre a sua condição e a da sociedade negam-lhe o direito do vaticínio e da intemporalidade." A consciência da multiplicidade no tempo e no espaço, percebida no romance de Luft, torna-o ainda mais crítico, mesmo que tal criticidade esteja oculta pela subjetividade. Ao tratar-se do tempo, por exemplo, o "eu" estabelece concomitantemente a voz do presente, o resgate do passado e a possível projeção do futuro. Sua tentativa de intemporalidade está na decisão de ser sempre criança e, principalmente, no aprofundamento do tempo interior que provoca a queda do tempo cronológico. A desestrutura do tempo linear e a volta do tempo circular, percebidas no romance luftiano, são, portanto, o retorno à intemporalidade mítica analisada por Rosenfeld (1996, p.91), e expressa "um mundo em que a continuidade do tempo empírico e o eu coerente e epidérmico já não têm sentido." As ruínas (ou fragmentos) do mundo exterior são vistas através do fluxo psíquico do narrador, motivo pelo qual não nos aproximamos de um mundo, e sim de vestígios de uma mente individualizada, abandonada à angústia. Steiner refere-se às ruínas dos tempos modernos, que devem ser vistas como uma possibilidade de recomeço às agudas reflexões sobre literatura e sociedade. Para ele, vivemos o depois, fato que já traz a nós ainda mais responsabilidades no processo de (re)humanização: 
Nós vivemos depois, e esse é o ponto nevrálgico de nossa posição. Depois da ruína, sem precedentes dos valores e esperanças humanos resultantes da brutalidade política de nossa época.

Essa ruína é o ponto de partida de qualquer reflexão séria sobre literatura e sobre o lugar da literatura na sociedade. A literatura lida essencial e constantemente com a imagem, com a forma e o estímulo da conduta humana. (Steiner, 1988, p.22). (Grifo do autor).

O ponto cego é um romance feito de ruínas, pois representa a fragmentação, a ausência e o vazio sobre o que se foi por meio das memórias individuais. Pelo olhar oblíquo do narrador, propõe perspectivas críticas sobre o mundo moderno, feito de sombras e esperança. No romance, a morte está contida na vida, o inusitado é encontrado no cotidiano, a solidão entrelaça-se à esperança, e o passado desloca-se para o futuro. Essas presenças latentes possibilitam a permanente reinvenção individual. Essa ambivalência vai ao encontro da estrutura pertencente ao romance enquanto elemento literário fundado na sociedade moderna, e em sua relação com o isolamento do "herói" destronado. Octavio Paz descreve e analisa essa estrutura cambiante, que é impura por ser plural:

Ritmo e exame de consciência, crítica e imagem, o romance é ambíguo. Sua essencial impureza brota de sua constante oscilação entre a prosa e a poesia, o conceito e o mito. Ambigüidade e impureza que lhe vêm do fato de ser o gênero épico de uma sociedade fundada na análise e na razão, isto é, na prosa. (Paz, 2003, p.69). 
O papel social das personagens no romance é remexido ou degradado por dois símbolos presentes na obra de Luft: o espelho e a máscara. O primeiro é o elemento através do qual o indivíduo fica em suspenso e, como ocorre com o Menino, quase não se reconhece quando recebe o reflexo de si mesmo. O segundo é o elemento através do qual ele se esconde do mundo e se desloca na tentativa de fugir de si e de ser outro (re)padronizado. As máscaras sociais comprometem a essência do ser, causando vazio interior. De acordo com Farinaccio (2002, p.3;31),

As referências a máscaras e espelhos constituem uma linha de força importante no romance brasileiro contemporâneo. Em sua quase totalidade, essas referências estão associadas à necessidade de identificação do "eu" por personagens muito abaladas existencialmente. $[\ldots]$

O sem-rumo das personagens do romance brasileiro, contudo, constitui uma linha embaralhada, não retilínea, e certamente não apropriável pela ideologia do "progresso contínuo".

A sensação de "sem-rumo" está presente nas personagens de O ponto cego, as quais não vêem em suas vidas o "progresso contínuo" que o mundo ocidental imperante prega vigorosamente na atualidade. Não apenas o Menino fica sem ter para onde ir, mas também a irmã e o Pai, tais como astros isolados no céu. Ela, depois de todos os laços perdidos, estava "mais fria, mais dura [...]. À noite ficava sentada sem dormir diante da janela: ainda esperando, ainda querendo entender [...]" (Luft, 2003, p.136) 
Buscas e dúvidas presentes nas personagens excluem qualquer segurança em relação ao mundo. Ao contrário, as interrogações do Menino são também as suas, as nossas, as dos seres humanos que resistem à resignação cega. "A gente não pode inventar um cavalo num jardim na cidade. Ou pode?" [...]" (Luft, 2003, p.141). Essa pergunta aparentemente infantil traz em si o olhar do narrador sobre as estruturas padronizadoras da sociedade, que dificultam o pensar crítico devido aos códigos regulamentadores, representados na obra pela imagem do Pai. Não há um completo apagamento da exterioridade, mas a progressiva ampliação dos espaços íntimos, secundarizando os espaços alheios aos "eu". A lucidez da autoconsciência talvez tenha o poder de superar a alienação que paira sobre as relações eu $x$ outro na sociedade de consumo do final do século XX. De acordo com Eco (2003, p.228), “Alienar-se em algo significa renunciar a si mesmo para entregar-se a um poder estranho."

A avó do Menino renuncia a sua identidade ao ser dominada pelo consumismo, cuja ideologia valoriza a beleza contida nas aparências, descartando a que encontramos nas experiências internalizadas ao longo dos anos, com o chegar da velhice. Antes de ter sido liberta pela loucura, "Olhava-se nos espelhos procurando uma primeira ruga, uma primeira dobra. Uma primeira manchinha." (Luft, 2003, p.44). Plásticas removeram de sua face a verdadeira imagem, tornando-a uma desconhecida. A ilusão da eterna juventude, levada às últimas consequências, transportou-a das correntes da alienação para as asas da insanidade.

Assim como há a tentativa de reter o passado por parte a avó, também percebemos a de controlar o futuro por parte do Menino. Os anos de 1990 carregaram a arrebatadora espera do futuro próximo, contida no advento da tecnologia virtual dando a impressão de aproximação entre futuro e presente - e na ideia de virada do milênio - oferecendo a ilusão de "chegada ao futuro" pela humanidade. Essa busca 
consciente do amanhã, disseminada nos últimos anos, responsabilizou ainda mais os indivíduos por suas escolhas, ampliando culpas e desilusões. Em O ponto cego, é marcante a presença desse futuro que trai e atrai, não apenas o futuro pessoal, mas o futuro incerto da humanidade: “O que seria? O que viria? O que pendia no ar, pesado e fechado e perfeito, decisões tomadas, o golpe dado, assinados os acordos e feitos os nós?" (Luft, 2003, p.122). Como efeitos desse paradoxal "futuro", temos no romance a Morte Inominável, a loucura, a velhice, a solidão, e a tentativa de recomeço em meio às ruínas do passado familiar.

\section{Considerações finais}

A pluralidade do tempo e do pensamento é constante no romance de Lya Luft, aproximando-se da multiplicidade proposta por Ítalo Calvino (2003), vista como símbolo da vida contemporânea. Já Alfredo Bosi vê a atualidade como um tempo do desencontrado, do "Renegado" equilíbrio, da contradição simultânea entre o supermoderno e o antimoderno, da resistência à totalidade humana:

A pós-modernidade que aceita o delírio do consumível e do descartável, do imediato e do competitivo, não tem recursos mentais e morais para enfrentar a dissipação dos bens, a disparidade das rendas, o desequilíbrio dos poderes e status. A recusa ideológica de olhar para o todo natural-humano, que nos constitui e convida a ser-no-mundo, pode dar-se ares de modéstia epistemológica [...]; mas, a longo prazo, quem a sustenta como programa de pensamento e ação irá perdendo todo critério de valor, e se verá cúmplice das forças da desintegração e da morte. (Bosi, 1993, p.357). 
A desintegração que ocorre na obra perpassa as fronteiras entre o real e o imaginário, possibilitando leituras a respeito do cotidiano e suas arbitrariedades. Entre elas encontramos a indiferença ao social resultante da amplitude interior: "Ficamos quietos de mãos dadas sem ver nada do que se passa lá fora. Na rua a vida continua como sempre, gente e carros, e o sol indiferente." (Luft, 2003, 54). Outros pontos de contato entre mundo interior e exterior são visíveis ao longo da narrativa: a superficialidade dos relacionamentos familiares, tais como os vínculos entre o Menino, a sua irmã e o Pai; as traições no seio familiar; a relatividade das verdades sobre as quais os indivíduos se amparam; a desigualdade provocada pelas relações de poder; a fuga e a resistência pessoal frente à realidade; a alienação e suas relações com a modernidade; as violências diárias; a relação porosa entre o "eu" e o mundo.

Além desses contatos entre a obra e seus vínculos sociais, ainda percebemos as precariedades existentes nos relacionamentos, enfatizadas nas reflexões do Menino. Para ele, há portas perigosas na intimidade que, quando abertas, reviram a existência, como se o vento assobiasse dentro desses espaços ocultos. Os que têm medo de expor a interioridade conservam-nas cerradas com as chaves dos silêncios e das aparências:

O que a gente sabe mas não diz pesa mais do que o pronunciado, pois move-se nas brumas e escapa de qualquer vigilância. Os silêncios de minha Mãe são mais densos que os gritos de meu Pai. Eu andar sozinho de noite é mais triste do que o olho azul dele. Os pensamentos de minha Avó eram mais loucos do que a gente admitia. A vida de tio Nando foi podada e não se conserta mais.

Tudo é pior quando escorrega para o fingido esquecimento. 
Tudo é fingido nesta vida, e todo mundo sem falar nisso participa. A gente não fala. Porque seria abrir uma porta muito perigosa. (Luft, 2003, p.86).

A referência da personagem nos leva à simbologia do Barba Azul: "Parecemos estar no castelo do Barba Azul. Pela primeira vez a inteligência ambiciosa de futuro de nossa espécie, que é um exemplo de evolução sistemática tão intrincada quanto vulnerável, vê-se diante de portas que talvez fosse melhor deixar fechadas. Sob pena de vida." (Steiner, 1990. p.183). A escolha da personagem em abrir ou fechar uma porta é individual, mas as consequências recaem na outridade. Seus perigos não apenas se referem ao ato de abrir a porta errada, como acontece na história do Barba Azul, mas ao de descortinar um mundo grotesco e, ao mesmo tempo, fechar caminhos que poderiam levar a possibilidades de socialização. Sem saber o que fazer, o Menino é "mais um personagem atrás das portas" que já abriu pelo ato da criação literária, reconduzindo a dor de suas escolhas. É nessa medida que o intimismo latente em O ponto cego interage com a realidade de seu tempo.

A realidade exterior ao romance, transfigurada no ato de criação, é controlada pela imaginação, que une fantasia e experiência, e pela linguagem, que a torna visível. Tudo é filtrado da visibilidade do autor, que transposta o seu ponto de vista para a do texto. Esse processo entre exterioridade e interioridade pode ser percebido em cada fio que o narrador costura na narrativa, através de seu olhar polimorfo.

O ponto cego, em sua vitalidade intimista, é representativo da problemática social inerente à modernidade, não apenas pelo conteúdo reflexivo que comporta em meio à problemática vivida pelas personagens, mas principalmente em seus aspectos estéticos transgressores à narrativa tradicional. Suas características poético-ficcionais conferem ao texto uma soma de gêneros e formas. Lya Luft estabelece, por meio desse romance, a 
releitura da ambivalência humana, oscilante entre o "sim" e o "não", entre o abrir e o fechar de portas, posicionando-se, ao longo da narrativa, em prol de um olhar para a vida que renasce em uma perspectiva diversa daquela imposta pelas consequências da modernidade nas sociedades de consumo. “Tudo é, portanto, uma questão da posição do escritor diante da realidade do mundo que representa." (Auerbach, 2004, p.482).

\section{Referências}

Auerbach, Erich. Mimesis. 5. ed. São Paulo: Perspectiva, 2004.

Barbosa, João Alexandre. As ilusões da modernidade. São Paulo: Perspectiva, 1986.

Benjamin, Walter. Rua de mão única: obras escolhidas. 4. ed. São Paulo: Brasiliense, 1994. V.II.

Benjamin, Walter. Documentos de cultura, documentos de barbárie: escritos escolhidos. Seleção e apresentação de Willi Bolle. São Paulo: Cultrix; Universidade de São Paulo, 1986.

Bosi, Alfredo. Post-Scriptum. In: __ Dialética da colonização. 2. ed. São Paulo: Companhia das Letras, 1993.

Bosi, Ecléa. Memória e sociedade. 3. ed. São Paulo: Companhia das Letras, 1994.

Brait, Beth. A personagem. 7. ed. São Paulo: Ática: 2004.

Calvino, Ítalo. Seis propostas para o próximo milênio. 3. ed. São Paulo: Companhia das Letras, 2003.

Candido, Antonio. A personagem do romance. In: CANDIDO, A. et al. A personagem de ficção. 10. ed. São Paulo: Perspectiva, 2002.

Colasanti, Marina. A moça tecelã. In: LADEIRA, Julieta de Godoy (Org.). Contos brasileiros contemporâneos. São Paulo: Moderna, 1991. 
Costa, Maria Osana de Medeiros. A mulher, o lúdico e o grotesco em Lya Luft. São Paulo: Annablume, 1996.

Eco, Umberto. Obra aberta. 9. ed. São Paulo: Perspectiva, 2003.

Farinaccio, Pascoal. A questão da representação e o romance brasileiro contemporâneo.. In: Estudos de Literatura Brasileira Contemporânea, Brasília, ago. 2002.

Leite, Ligia Chiappini Moraes. O foco narrativo. 8. ed. São Paulo: Ática, 1997.

Luft, Lya. O ponto cego. 4. ed. Rio de Janeiro: Record, 2003.

Mesquita, Samira Nahid de. O enredo. 3. ed. São Paulo: Ática, 2003.

Paz, Octavio. Ambigüidade do romance. In: . Signos em rotação. 3. ed. São Paulo: Perspectiva, 2003.

Rosenfeld, Anatol. Reflexões sobre o romance moderno. In.: Texto/contexto I. 5. ed. São Paulo: Perspectiva, 1996.

Rosenfeld, Anatol. A visão grotesca. In: __ Texto/Contexto I. 5. ed.São Paulo: Perspectiva, 1996.

Silva, Simone Sampaio. Nas fronteiras do inteligível: O Ponto Cego delineando um novo traço na ficção de Lya Luft. In: Mulheres e literatura (revista virtual). v. 6, Rio de Janeiro: 2001.

Disponível em:<http://www.letras.ufrj.br/litcult/revista_mulheres/volume6/64_simone.html>. Acesso em: 14 out. 2004.

Steiner, George. Alfabetização humanista. In: . Linguagem e silêncio. São Paulo: Companhia das Letras, 1988.

Steiner, George. Linhas da vida. In: . Extraterritorial: a literatura e a revolução da linguagem. São Paulo: Companhia das Letras, 1990. 